\title{
FRANK LLOYD WRIGHT, AYN RAND AND HYPER-CAPITALIST UTOPIA
}

\section{A B S T R A C T}

This paper is a parallel reading of Frank Lloyd Wright's treatise Disappearing City and Ayn Rand's novel The Fountainhead. The author explores the rhetoric of anti-urban utopias of the Depression-era inspired by the myth of the American pioneer and the conquest of the frontier. She identifies three characteristics of Wright and Rand's anti-urban constructs: the celebration of virility, the denial of political engagement and anti-intellectualism, all combined in the dream of primordial, ideal capitalism. What are the contradictions and inconsistencies inherent in building an anti-urban utopia? This is the question this paper intends to answer. 


\section{INTRODUCTION}

Ayn Rand's novel The Fountainhead, written in the 1930s and published in 1943, and Frank Lloyd Wright's Disappearing City of 1932 are among the most important architectural utopias of the Depression era. The two are connected, not only because they belong to the same historical context, but because Wright's persona was direct inspiration for Rand, who, in writing the novel and the script of a film based on it consulted him for both projects. The famous novel, which is still being sold in hundreds of thousands of copies and the architectural treatise that elaborates on Wright's planning ideals share the same attitude, as passionate condemnations of American urban life and posit the figure of the hero-architect as the prophet of an alternative, ideal society.

Critiques of the relationship between Rand's politics and her understanding of architecture in The Fountainhead center on notions of virility that Rand constructs when describing the heroic architect. According to Schleier, in her analysis of the film The Fountainhead of 1949, the sexuality of Rand's protagonist Howard Roark is a projection of the social aspirations and dreams of the Depression-era unemployed. ${ }^{1}$ For Hoberek, the intended readership of Rand's works is the disenfranchised white-collar class, heir to the propertied petite-bourgeoisie. ${ }^{2}$ In Stockton's radical interpretation, Rand's virile hero expresses American fascist proclivities, the desire for an übermensch whom the masses can identify with. ${ }^{3}$

Wright's Disappearing City as an architectural utopia is usually discussed in terms of Wright's participation in the Jeffersonian anti-urban tradition. For Morton and Lucia White his work is the final (architectural) stage in the history of American intellectuals' condemnation of urban life, which marks American cultural tradition since its inception. ${ }^{4}$ Tafuri famously analyses this tradition, and Wright's status as a key figure in the development of capitalist utopia. His Marxist stance is that capitalism's utopias are a reaction to the modern "shock derived by the experience of the metropolis." ${ }^{5}$ From Jefferson onwards, this ideology is the denial, reaction to, or concealment of the true nature of the city "structured as a machine for extracting surplus value" that lies at the center of "capitalist ideology." " All capitalist utopias, and especially agrarianism from Jefferson to Wright, can only be regressive, since they do not acknowledge the true logic of capitalist production and its ultimate materialization: the modern city.

By reading Rand and Wright in parallel, I will try to establish connections between these two lines of inquiry about the politics of the 1930s American utopian vision. The nature of the architect's social position and agency, primarily 
discussed in literature about The Fountainhead, can be explored together with the status of modern utopia in the anti-urban discourse. Wright's work, without doubt, can be read as part of the long tradition of American agrarianism. But it is marked by historical and discursive particularity, which can be grasped in its relation to another radical narrative of its own time. By focusing not only on general ideas, but also on the workings of radical anti-urban rhetoric, it is possible to go beyond the Marxist notion of a relatively uniform and consistent 'capitalist ideology' and to analyze the anti-urban utopian visions of Wright and Rand in terms of their discursive particularities. What I want to explore is not the relationship of these utopias to the 'real' conditions of production but their internal logic and language, as two among many discourses and material practices that form the heterogeneous landscape of capitalist symbolic production. Wright's and Rand's texts are perhaps the most extreme programs for capitalist democracy and shedding light on their internal logic can shed light on the limitations and internal contradictions of capitalist political aspiration.

\section{ANTI-URBANISM AND RIGHT-WING UTOPIA}

In both Wright's and Rand's work utopia is intricately connected with a renunciation of the contemporary city, and with the aspiration to find alternatives to the culture of the Depression-era urban culture. How does this disavowal manifest itself and what are the peculiar characteristics of their utopian vision, as elaborated in The Fountainhead and The Disappearing City?

Wright's confrontation with modern urban life in The Disappearing City starts with the frontispiece to the book. It is a photograph of New York obscured by fog and factory fumes, emanating from the factories in the foreground (Fig. 1). Only the peaks of the very tallest skyscrapers are visible at the top of a gigantic cloud extending across the metropolis and enveloping it completely. This scene can be a picture of just another foggy or smoggy day. Or it can be a rendering of the city after Armageddon: some gigantic explosion, filling the streets with alldevouring dust. The picture figures in the book not as a documentary recording, but as metaphor for the city's horrors, and also, in many ways, as illustration of the proposal which Wright discusses in the book: the plan to replace the American metropolis with an endless suburban semi-agrarian development spreading over the entire continent.

What Wright propagates is 'Usonia,' the American way of life. The idea is that the American continent should be transformed into a landscape of one-acre plots, surrounded by roads and highways, with essential communal amenities, such as schools and marketplaces. The owners of one-acre plots exchange goods by barter, and till their land to grow food. The fog-enveloped city in the 
frontispiece is followed by another image, that of life "Beyond the Vortex" (Fig. 2 ), in which urban horror is replaced by the tranquility and beauty of country fields. The ominous stratus above the city is replaced by a lovely cumulus, floating above this agrarian paradise. Here the citizen reappears as a peasant woman, ostensibly as fertile as the freshly harvested fields she is associated with, with their stacks of fragrant hay, awaiting the birth of the new American.

It is the very absence of architectural renderings and the inclusion of photographs instead that, according to Wright, qualifies this work as the essential and farreaching vision for Usonia. He wants to present the "ideal," rather than a particular form. According to him, that "ideal" is "fixed" by the architect in writing, new architecture will follow. ${ }^{7}$ What the images do is that they do not present a vision, but 'document' urban dystopia and its alternative, signaling that the "ideal" is based on utopian and dystopian realities, which the architect can engage with by transforming the material environment.

The transformation (the logic and makeup of Usonia) is presented in narrative form. And, essentially, Wright's work is a piece of utopian fiction. He establishes the dialectical relationship between 'vision' and 'fact' as a dialectical relationship between text and image. In this sense, Wright's manifesto is similar to Le Corbusier's Toward a New Architecture. But the fundamental difference is that in The Disappearing City architecture, in many ways, is revolution, and that the work is a proclamation of an architectural, but also political program. Usonia is an architectural project, but its foundation is a political project. The design of Usonia is based on essential Usonian values: the right to private property, individualism, and the abolishment of central government.

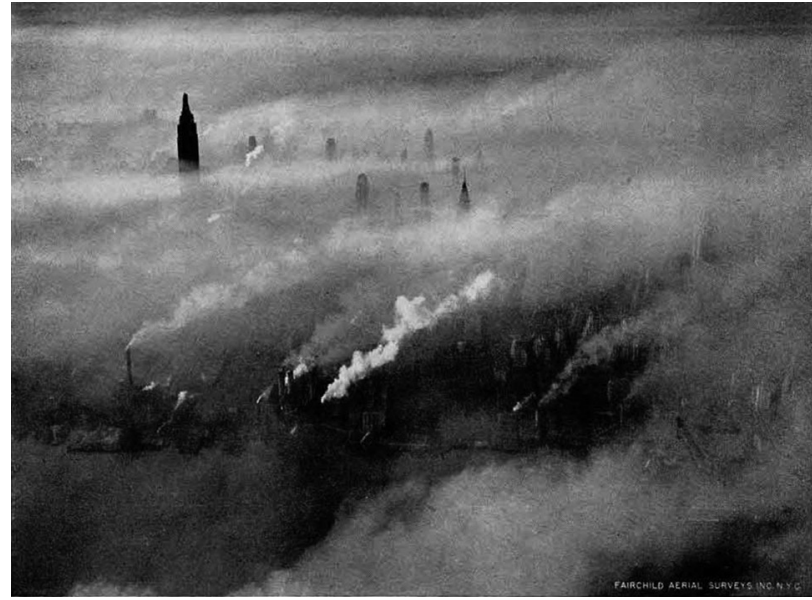

Figure 1. Frontispiece in Frank Lloyd Wright, The Disappearing City (1932)

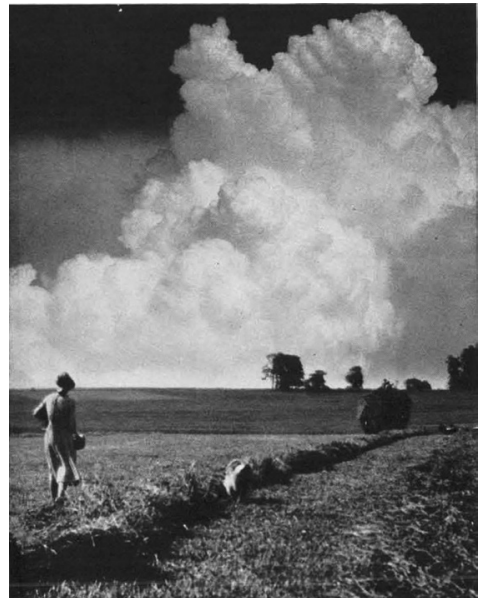

Figure 2. "Beyond the Vortex," in Frank Lloyd Wright, The Disappearing City (1932) 
It is not only that The Disappearing City differs, in the very concept of what architecture can do, from the most important architectural manifesto of its time. It is unique in the entire tradition of literary utopia to which it belongs. Historically, most modern utopias portray an ideal township, starting with Thomas More's city of Amarat, ${ }^{8}$ and continuing, for example, with Bacon's New Organon ${ }^{9}$ and William Morriss's News from Nowhere. ${ }^{10}$ And even Le Corbusier's 'functionalist' utopia is that of the most efficient city. In Wright's the city is about to disappear. Politically, what characterizes Frank Lloyd Wright's agrarian utopia is that it is a right-wing, rather than a left-wing one. Peter Fitting discusses this difference, and the rare phenomenon of right-wing utopia, in his article "Utopias beyond Our Ideals." of left-wing utopias, according to Fitting, are the abolition of private property rights and the idea that a strong and enlightened government should guarantee the equality of the citizens. Most utopias are left-wing, from the early modern visions to the Communist project, which has traditionally been identified as a utopian one. But Wright's utopia, in contrast, celebrates the dissolution of government and the ideal of universal private property, the ownership of oneacre plots in the idyllic countryside.

Wright explicitly situates himself in the Jeffersonian tradition, citing as his guiding principle the motto he attributes to Jefferson, "That Government which is the best Government is that which is the least Government." ${ }^{12}$ In Architecture and Utopia Tafuri uses the examples of Jefferson and Wright to show the regressive nature of capitalist utopia. According to him, capitalist utopia emerges as a nostalgic reaction to industrial development (and its manifestation, the city) and a harkening for the pre-industrial past as its alternative. ${ }^{13}$ Considering Wright's photographic illustrations to The Disappearing City, this seems to be the case. But there is more to Wright's discourse. His animosity towards the city is not merely a desire to retreat, or to disavow capitalist development. $\mathrm{He}$ advocates the use of modern technology (a most prominently the car) in order to produce a better version of industrial capitalism, a hyper-capitalism of the universal right to private property and its exploitation. And he claims that such a system would be possible precisely because of new opportunities presented by modern technology for a "nomadic" mode of life in the expanses of the American continent and provide for "mechanical mobilization." 14 There would be no government; Usonian life would be ordered by the architect instead.

The ardor for individualism, free market exchange, and the rejection of centralized government authority, according to Fitting, are the tenets of the most important genre of right-wing utopia, the libertarian one. ${ }^{15}$ His primary example is the work of Wright's contemporary, Ayn Rand. Fitting notices that, 
for the most part, Rand does not devote much time describing utopia, except for political ideals that would drive it, such as the right of the individual to personal striving, power and liberty, and the freedom from stifling bureaucracy and mediocrity of the mob.

Ayn Rand's novel The Fountainhead of 1943 sold in a million copies as the most popular interpretation of Wright's work and persona. Although the objectivist libertarian philosophy of Ayn Rand, according to which ethics is based on selfishness, differs from Wright's ideal of "selfhood" without "selfishness," 16 which he promotes as the central value of his utopian society, the two are closely linked. The Fountainhead is based on interviews with Wright, canonizing him arguably more than his own writing. Set in the city, The Fountainhead provides a dystopian vision of urban life, which complements Wright's agrarianism, and reflects some of his criticism of urban life. The Fountainhead presents a grim vision of the city and a portrayal of the architect-genius as a figure which embodies the American ideal, and lives according to Rand's philosophy of individualism. The novel's hero, Howard Roark, the genius self-taught modernist architect who is not understood by his philistine, duplicitous, and career mongering colleagues and critics: the urban establishment. Roark, the urban visionary, suffers, but bears the suffering completely confident in his talent and driven by his passion, is determined to build his modernist vision. He asserts his creative rights by destruction: by blowing up a mass housing project he designed because it was altered by others. In court, he defends himself explaining the role of great men, such as himself, in the development of civilization and is acquitted.

Wright's and Rand's works are closely tied in their celebration of unfettered individualism and anti-urban attitude, as well as by the fact that they see the architect as a demiurge and model for the New Man. What is the logic of these narratives? How are anti-urbanism and right-wing politics connected? How does the heroic architect figure in this narrative as the model for the utopian subject? And, finally, is anti-urban utopia entirely consistent? I will try to tackle these questions by looking at the three basic components in the rhetoric of The Disappearing City and The Fountainhead: the ideology of the denial of ideology, hyper-masculinity, and anti-intellectualism.

\section{THE IDEOLOGY OF THE DENIAL OF IDEOLOGY}

One possible definition of utopia which can be proposed in reference to classic modern examples is that utopia portrays the ideal life of a collectivity in the ideal city. This can apply to left-wing utopias, especially those in which the ideal city 
is a haven for the working class and a site of new collectivism. But this does not seem to be pertinent in the cases of Wright and Rand. Utopian life in Broadacre, for one, is not the new life of the collective, or the working masses. It is the life of individuals "conveniently enough spaced." ${ }^{17}$ Wright explicitly denies that his modernist values are political. "Necessarily," he writes, "this has nothing to do with capitalism, or communism, or socialism. The 'ism' in any form does not have any individuality." ${ }^{\prime 18}$ Rand places blame for urban hell directly on socialist politics. The preacher of socialism in The Fountainhead is Ellsworth Toohey, the art critic and socialist leader who has as his mission to destroy Roark/Wright as a non-conformist individual. She has Ellsworth Toohey say: "Everything $[\ldots]$ is contained in a single word - collectivism. And isn't that the god of our century? To act together. To think - together. To unite, to agree, to obey, to serve, to sacrifice." ${ }^{\prime 19}$ But she considers this cynical. Toohey is the prototype of an "ideologue," driven by the will to power rather than an altruist impulse. "Divide and conquer - first," he says after his collectivist rant. "Then - unite and rule. Remember that the Roman Emperor who said he wished humanity had a single neck so he could cut it?" ${ }^{20}$

The ideology of the denial of ideology in the name of individualism is one of the main characteristics of Rand's and Wright's anti-urban stance and what renders it unique. But is it true that Wright and Rand articulate the universal aspirations of the American bourgeois class? Recent writing of Andrew Hoberek offers an interesting perspective on this issue. Hoberek proposes that the 1930s and the 1940s fiction and Rand's work in particular, offer a sense of agency to a particular group: the disenfranchised middle class. ${ }^{21}$ In his opinion, this disenfranchisement, which started with the railroad monopoly in the nineteenth century, and became more pronounced during the Great Depression entailed the transformation of the petty-bourgeoisie from a property-owning class to that of white-collar workers, whose agency based in small property ownership, is erased once they became peons corporate bureaucracies. Wright explicitly writes about the emergence of the "army of white collarites," the "major and minor petty officials" as a threat to democracy. ${ }^{22}$

What Wright and Rand offer to the disenfranchised petty-bourgeoisie is a fantasy of power. This fantasy is based on identification with the figure of the great architect and a utopia of liberty based on property ownership in Wright and on the autonomy of mental labor as sacrosanct intellectual property (in Rand). In both works, the fantasy is intricately linked with the legend of the American pioneer, as a self-sufficient entrepreneur-conqueror. This legend is situated in the reinvented past: the proto-capitalist condition of a free-for-all 
land and capital accumulation. The struggle for proto-capitalism, however, is not the struggle for return to a real past. Rather, the dream of the frontier as a dream of universal private property is not a direct return to history. It exists in future anterior, as an imminent realization of the idealized American past, a utopia in which the dream, rather than the reality of the frontier will finally materialize, as a universal American dream that fulfills everyone's desires and is thus not impacted by politics.

The renunciation of politics and the renunciation of the polis are two sides of the same coin. However, what is interesting about this renunciation is that it is not a matter only of abstract principle, but rather an aesthetic choice. Antiurban position is articulated as a visceral reaction to the crowdedness of the city and the threat of cramped mass existence. In Warped Space Anthony Vidler points out how the writing of Ayn Rand expresses a feeling of claustrophobia, of fear of the crowd. It manifests itself ultimately in the fear of touch, with her characters either avoiding physical contact all together, except when the two main protagonists, Howard Roark and Dominique Francon fall into sexual frenzy. ${ }^{23}$ This feeling of entrapment leads the author to search for a limitless, "ineffable" space in which she would escape from urban claustrophobia and suppress the anxiety of metropolitan experience. Wright's fear of the mass, of the crowd, is no less prominent. The Disappearing City begins with depictions of urban anxiety, as the anxiety of mass existence. The citizen feels the horrifying "warmth and pressure" of the crowd, surrenders to "herd-instinct." 24 He shares the "instincts of the amorphous human herd," which "swarms in the erthswile village streets. ${ }^{25}$ His nostalgia is the nostalgia for a life in which people were "conveniently enough spaced." 26 And he presents a plan for the "ineffable" space which Rand desires. Ultimately, a political choice is an aesthetic choice, and the petite-bourgeois 'ideology of the denial of ideology' in Wright and Rand is presented as an aesthetic desire: a desire for a new kind of sensory experience.

\section{HYPER-MASCULINITY}

The sense of empowerment that Wright and Rand offer the reader is based on identification with the heroic individual, embodied in the figure of the architect as both a builder and destroyer, who liberates humanity from the captivity of the city and herd-like existence. If there is no explicit 'ideology,' there is a key identification. In Wright that is the nostalgic identification with the brave pioneer. In Rand, it is the identification with the misunderstood genius, who ultimately triumphs in his battle for recognition and creative freedom. 
What is interesting here is that male heroism is highly sexualized and presented not as political agency, but as the experience of great virility. For Wright the citizen of Broadacre, a "manly man," ${ }^{27}$ "impregnates" new life. ${ }^{28}$ Work "emasculates" the man. ${ }^{29}$ The citizen can find no "physical release. ${ }^{.30}$ Creativity is reduced to "impotence." ${ }^{31}$ But in Broadacre he will be "impotent" no more. He will finally begin to "live in a manlike freedom." ${ }^{32}$ Ayn Rand also presents political and social agency using sexual motifs. The Fountainhead contains the highly controversial scene where Roark makes a woman fall in love in him by raping her. ${ }^{33}$ In another passage in the novel, the architect is described using his pen in what can be termed a masturbatory manner. Thus we have scenes such as this one: "Roark looked at the clean white sheet before him, his fist closed tightly about the thin stem of a pencil. He put the pencil down, and picked it up again, his thumb running softly up and down the smooth shaft; he saw that the pencil was trembling. ${ }^{.34}$ His physical work is also akin to the penetration of a woman. When Roark temporarily works on the construction site, he "holds his fists tight" around the drill," "keeps his feet steady, pressed down hard, the flat rock an upward thrust against his," to feel "the existence of his body, but only a few clots of tension: his knees, his wrists, his shoulders and the drill he holds - to feel the drill trembling in a long convulsive shudder - to feel his stomach trembling, his lungs trembling [...] to feel the drill and his body. " 35

The experience of agency and power is represented as sexualized experience: that of extreme virility and masculine erotic pleasure. Sharon Stockton has explicitly discussed Rand's writing, and, in particular, the rape scene in The Fountainhead in terms of the cult of virility, relating her ideas to the interwar American cult of the engineer as "the man." ${ }^{\text {" }}$ According to her interpretation, this cult of virility corresponds to fascist ideas of the übermensch and represents the American 1930s version of fascism as identification with the potent leader and the desire for totalitarian control expressed as sexual control of the female body. However, the American Randian version differs in two respects. Unlike the European fascist movements, which celebrated what Rand calls "the warmth and pressure" of the masses and the loss of individual identity, for the two anti-urban utopians this oceanic feeling is the source of anxiety and distress and the very sensual phenomenon they are up against. The battle for utopia was the battle of the individual against the polis.

The experience of supposedly a-political personal agency is presented again as a visceral experience, and it is in Rand accompanied by a particular aesthetic template for the virile hero which somewhat resembles the Arian ideal. Roark, who in the very opening paragraph of The Fountainhead appears in the nude, resembles a classical stature, his muscular body seemingly one with the rock 
on which he stands. He stands tall, with flaming red hair, and captivates his interlocutors with the sheer power of his body and the sharpness of his penetrating gaze. Political, social agency has to be literally fleshed out in the representation of the heroic body.

\section{ANT I - INTELLECTUAL ISM}

The antithesis of the virile macho architect is the intellectual. He is, of course, physically repulsive. Roark's nemesis, art critic and journalist Ellsworth Toohey, has a body "like that of a chicken emerging from an egg, with all the sorry fragility of unhardened bones. ${ }^{37} \mathrm{He}$ was declared on birth unfit to survive, was always sickly as a child, which is why he became interested in books instead of sports. He was not even manly enough to be good in mathematics. Instead he learned history, English, civics, penmanship, psychology and sociology, the suspicious humanities which build a feeble character. He went to Harvard. And, of course, he was not ever interested in sex, unlike the potent and virile Roark.

Rand's portrayal of the intellectual resonates with Wright's ideas about the intellectual class. For Wright "bookology" and the "big knowledge-factory" are the main source of "impotence." 38 "All culture came to be selected," he writes, came to be "artificially adapted and soon was, by way of education, arbitrarily applied by academic advice to growing power and to developing resources." 39 But it failed, according to Wright, "to qualify as impregnator of new life or as adequate interpreter of the new ideal on which the life of the country was initially founded." ${ }^{40}$ In his repulsion for "bookish" learning in Broadacre Wright intends to make schools as small as possible. Instead of history, literature, rhetoric, "bookish" knowledge, he is going to teach drawing and ploughing. ${ }^{41}$

The appearance of Usonia, the land of the pioneer-like self-made man would eliminate, together with the metropolis, the entire urban elite. In The Disappearing City the intelligentsia is described as what Althusser would call the "ideological State apparatus" 42 : its members are officials whose "complex rulings becomes this official [urban] army." ${ }^{, 33}$ An army which supports the rule of what Wright calls the "machinelords" and the "moneylords." military fortress, and its role is to safeguard the "moneylords" and their army of intellectuals. In Rand, the antiheroes whom Roark has to confront are members of professional guilds who organize to defend their power and dominance, power acquired through inheritance, family connections, and the like. Roark's superior physical appearance signals that he is not part of this establishment. He builds his strong muscles by working as a "plumber, electrician, rivet catcher and "many other things," ${ }^{45}$ before becoming the architect-prophet. 


\section{CAN THERE BE AN ANTI-URBAN UTOPIA}

One way to understand the anti-urban attitude is to see it as a rebellion against the intellectual elite and its connections to capital. Literary, "bookish" culture is the culture of the white-collar elite in power and Wright and Rand rebel against it in the name of the social groups that inhabit the space on the margins of the citadel, be it, as Hoberek proposes, the white-collar clerk, or the inhabitant of the countryside. This is an important part of the appeal of their works. Education is not seen as merely the capacity to contribute to culture, but also a sign of power. What is the nature of this power? In order to answer this, I will look into the canonical articulation of urbanity and marginality, that is, Angel Rama's book The Lettered City. Rama writes about issues of class in the context of the urban and the sub-urban. His study is about the class of letrados in Latin America, the cast of the literate. They were not only authors, poets, artists, but also, and at the same time, the executors of colonial rule, which was based on the privileged access to letters. ${ }^{46}$ Rama's history can be seen as a story with broader implications of intelligentsia's power, not only in Latin America, but also in other modern cultures across the globe. The city, apart from being the locus where capital is concentrated, is also the locus of the concentration of knowledge, which determines social hierarchies and the relationship between haves and have-nots. To rebel against the city is to rebel against the intellectual establishment and its oppressive role, and with it, against social hierarchies. However, in advocating the destruction of the city and its social milieu, Wright and Rand replace one kind of authority with the fiction of the absolute authority of the architect as the author of the American utopian future and provide an impossible alternative.

But the anti-urban hyper-capitalist utopias are plagued by paradoxes. One is that the condemnation of the city as a site of suffocating, numbing, crowded life and its aesthetic of congestion is coupled with an aesthetic fascination with it. The other is that both Rand and Wright, in their rebellion against "bookish" culture decide to write - books.

Wright's and Rand's rebellion against city's power and the imagined victory of those on its margins would be quite simple if they merely expressed their disgust with the metropolis. But what is interesting is that their narratives betray a certain attraction that is married with their proclamations of repulsion. They condemn the politics of the city. But the very fact that this condemnation is expressed as an aesthetic choice makes the condemnation somewhat spurious when they admit fascination with it as an aesthetic phenomenon. The city is not only the seat of demoniac forces one must politically disavow; it is in a way a sublime appearance, fascinating and even attractive, and, as such, it cannot be completely renounced. Rand hates the powers embodied in the city: its institutions, patrons, 
architects, who rule yet cannot recon with creative genius. Wright writes against "superfluous millions," "adventitious fortune," the "landlords," "moneylords," who rob the American citizen of his birth right: the birth right of being a property owner. ${ }^{47}$ But, at the same time, Rand, as her protagonist Gail Wynand would put it, "would give the greatest sunset in the world for a view of New York's skyline. Particularly, when one cannot see the details. Just shapes." ${ }^{\prime 48}$ This vision is more powerful than religion, and pilgrims of modernity should "stand on the shore of Hudson, look and kneel." ${ }^{\circ 9}$ Despite dubbing the city a concentration of "exaggerated buildings" and "exaggerated enterprises," ${ }^{50}$ Wright also writes about its magnificence. His most famous manifesto, The Art and Craft of the Machine, ends with a long paean to the sounds, visions, movement of the city. It is a total rapture with "the voice of this monstrous thing this greatest of machines, the great city, [which] rises to proclaim the marvel of the units of its structure, the ghastly warning boom from the deep throats of vessels heavily seeking inlet to the water-way below, answered by the echoing clangor of the bridge bells growing nearer and more ominous as the vessel cuts momentarily the flow of the nearer artery, warning the current from the swinging bridge now closing on its stately passage, just in time to receive in a rush of steam, as a streak of light, the avalanche of blood an metal hurled across it and gone, roaring into the night on its glittering bands of steel, every faithfully encircled by the slender magic lines tick-tapping its invincible protection." ${ }^{51}$

Ultimately, even in radical program of anti-literary hyper-capitalism, there is no way to do away with the city. What testifies to this is the main paradox of Wright's and Rand's enterprises. Despite rejecting urban literate culture, intellectualism, they are writers themselves, and join the class of letrados. The Disappearing City and The Fountainhead are pieces of writing, pieces of literary fiction executed in the medium of urban "bookish" culture. It is a question whether it can be otherwise. There is no utopia without writing, and no politics without the polis.

NOTES

Merill Schleier, “Ayn Rand and King Vidor's Film 'The Fountainhead': Architectural Modernism, the Gendered Body, and Political Ideology," Journal of the Society of Architectural Historians, Vol. 61, No. 3 (Sep., 2002): 310-331.

Andrew Hoberek, "Ayn Rand and the Politics of Property," in The Twilight of the Middle Class Post-World War II American Fiction and White-collar Work (Princeton: Princeton University Press, 2005), 33-52.

Sharon Stockton, "Engineering Fascism: Ayn Rand, Ezra Pound, and the Virile Hero," in The Economics of Fantasy: Rape in Twentieth-Century Literature (Columbus: Ohio State University Press, 2006), 48-70.

Morton and Lucia White, The Intellectual versus the City, from Thomas Jefferson to Frank Lloyd Wright (Cambridge: Harvard University Press, 1962).

Manfredo Tafuri, Barbara Luigia La Penta, transl., Archtiecture and Utopia: Design and Capitalist Development (Cambridge: The MIT Press, 1976), 1.

Ibid., 81.

Frank Lloyd Wright, The Disappearing City (New York: William Farquhar Parson 1932), 84. Thomas More, Utopia (1516) (New Haven: Yale University Press, 1964). 
Francis Bacon, New Organon: True directions concerning the interpretation of Nature (1620). (Oxford, University Press, 1855).

William Morris, News From Nowhere or an Epoch of Rest, being some chapters from a utopian romance (1890). (New York: Random House, 1973).

Peter Fitting, "Utopias beyond Our Ideals: The Dilemma of the Right Wing Utopia," Utopian Studies, Vol. 2, No. 1/2 (1991): 95-109.

"The best government is that which governs least," motto of the United States Magazine and Democratic Review, 1837-1859, or "the less government we have, the better" - from Ralph Waldo Emerson's "Politics", 1844, sometimes mistakenly attributed to Jefferson. Cited in Frank Lloyd Wright, The Disappearing City, 10, 14.

Tafuri, Architecture and Utopia, 16, 120.

Wright, The Disappearing City, 6, 14.

Fitting, "Utopias beyond Our Ideals," 102.

Wright, The Disappearing City, 16.

Ibid., 20.

Ibid., 16.

Ayn Rand, The Fountainhead (London: Cassell, 1953), 593.

Ibid.

Andrew Hoberek, "Ayn Rand and the Politics of Property"

Wright, The Disappearing City, 10.

Anthony Vidler, "Framing Infinity: Le Corbusier, Ayn Rand and 'Inefable Space,"” in Warped Space: Architecture, Art and Anxiety in Modern Culture (Cambridge: MIT Press, 2000).

Wright, The Disappearing City, 3.

Ibid., 21.

Ibid., 30 .

Ibid., 63.

Ibid., 13.

Ibid., 36.

Ibid., 30.

Ibid., 13, 62, 84.

Ibid., 63.

Rand, The Fountainhead, 88.

Ibid., 196.

Ibid., 181.

Stockton, "Engineering Fascism".

Rand, The Fountainhead, 205.

Wright, The Disappearing City, 79.

Ibid., 13

Ibid.

Ibid., p. 80

Louis Althusser, Ben Brewster, transl. "Ideology and the Ideological State Apparatus," (1970), from Lenin and Philosophy and Other Essays (New York: Monthly Review Press, 1971).

Wright, The Disappearing City, 10.

Ibid., 4.

Rand, The Fountainhead, 78.

Angel Rama, John Charles Chasteeen, transl. The Lettered City (Durham: Duke University Press, 1996).

Wright, The Disappearing City, 30.

Rand, The Fountainhead, 441.

Ibid.

Wright, The Disappearing City, 11.

Frank Lloyd Wright, "Art and Craft of the Machine," in Frank Lloyd Wright: Essential Texts (New York: W.W. Norton and Co., 2009), 67. 
Althusser, Louis. Lenin and Philosophy and Other Essays. New York, 1971.

Bacon, Francis. The New Organon. Oxford, 1855. (Orig. 1620).

Fitting, Peter. "Utopias beyond Our Ideals: The Dilemma of the Right-Wing Utopia," Utopian Studies Vol. 2, No. 1/2 (1991).

Hoberek, Andrew. The Twilight of the Middle Class Post-World War II American Fiction and White-Collar Work. Princeton, 2005.

Le Corbusier. Toward a New Architecture. New York, 1927. (Orig. 1923).

More, Thomas. Utopia. New Haven, 1964. (Orig. 1515).

Morris William. News from Nowhere. New York, 1973. (Orig. 1890).

Rama, Angel. The Lettered City. Durham, 1996. (Orig. 1984).

Rand, Ayn. The Fountainhead. New York, 1953. (Orig. 1943).

Schleier, Merill. “Ayn Rand and King Vidor's Film 'The Fountainhead': Architectural Modernism, the Gendered Body, and Political Ideology," Journal of the Society of Architectural Historians, Vol. 61, No. 3 (2002).

Stockton, Sharon. The Economics of Fantasy: Rape in Twentieth-Century Literature. Columbus, 2006.

Tafuri, Manfredo. Architecture and Utopia: Design and Capitalist Development. Cambridge, USA, 1976. (Orig. 1973).

Vidler, Anthony. Warped Space: Architectture, Art and Anxiety in Modern Culture. Cambridge, USA, 2000.

White, Morton and Lucia. The Intellectual versus the City, from Thomas Jefferson to Frank Lloyd Wright. Cambridge, USA, 1962.

Wright, Frank Lloyd. The Disappearing City. New York, 1932.

Wright, Frank Lloyd. Frank Lloyd Wright: Essential Texts. New York, 2009. 


\section{ARHITEKTURA UTOPIJA REALIZAM: TEMATSKI OKVIR Ljiljana Blagojević}

Termin ili koncept realizma re-aktuelizovan je u skorašnjim teorijskim debatama od rasprava u filozifiji i estetici do onih u teoriji i praksi arhitekture. Počev od 2000. godine, arhitektonski diskurs se često bavi širokim spektrom srodnih pitanja koja proističu iz post-kritičkih rasprava o utopijanizmu i realizmu i mogućnosti jednog "utopijskog realizma", kako je to sugerirao Rajnhold Martin (2005). Rasprave o realizmu ponovo rezoniraju u arhitektonskoj teoriji kao odraz Manifesta novog realizma, filozofa Mauricija Ferarisa iz 2011 godine. Pitanja realizma naspram postmodernizma, "novog realizma" koji nastaje na pepelu post-modernizma, kritički i operativni pojmovi realizma i slično, postavljana su kako kroz prakse savremene arhitekture tako i kroz preispitivanje realizma i socijalističkog realizma u istoriji i teoriji arhitekture. Postavka tematskog okvira u ovom članku SAJ: Arhitektura Utopija Realizam ima za cilj da produbi tekuće rasprave o odnosima arhitekture sa realizmom i utopijom.

KLJUČNE REČI: ARHITEKTURA, UTOPIJA, REALIZAM, AUR MEĐUNARODNA NAUČNA KONFERENCIJA, UNIVERZITET U BEOGRADU - ARHITEKTONSKI FAKULTET

\section{UTOPIJA STVARNOSTI. REALIZMI U ARHITEKTURI IZMEĐU IDEOLOGIJE I FENOMENOLOGIJE Silvia Malcovati}

Predložen povodom Prvog Kongresa sovjetskih pisaca u Moskvi 1934 godine, pojam realizma u teorijskim raspravama o arhitekturi u ranim tridestim godinama dvadesetog veka, izgleda kao dvosmisleni pojam, koji se koleba između idealizma i ideologije, inovativnog istraživanja i istoricističkog formalizma. Neuspeh socijalističkog realizma i kriza njegove naglašene i monumenalističke arhitektonske slike, jasno pokazuju utopijski karakter realističkog "sna", ali isto tako, na neki način, njegovu maštovitu moć nastojanja da se izgradi bolji svet.

Pitanje realizma aktuelno je i posle Drugog svetskog rata. Posebno u Italiji realizmi se pretvaraju u alternative savremenoj paradigmi, ni manje ni više utopijski, već otvoreni prema novim postmodernističkim američkim idejama, kao i arhitekturi grupe "Tendenza".

U ovom radu predloženo je pregledno istraživanje realizama dvadesetog veka kao instrumenta koji odražava stanje u arhitekturi: nakon ekscesa postmodernog populizma, razočarenja "Architettura Razionale" i dijalektike rekonstrukcije - dekonstrukcije, izgleda da se ponovo pojavljuje u arhitekturi jedan novi bauk "Realizma" kao način reagovanja na trenutno arhitektonsko i urbano stanje.

KLJUČNE REČI: UTOPIJA, REALIZAM, ITALIJANSKA ARHITEKTURA POSLERATNOG PERIODA, “TENDENZA”, POSTMODERNIZAM, NOVI REALIZAM, ARHITEKTURA GRADA

\section{(SOC)REALIZMI U PRAKSI: PONOVNO ČITANJE SOVJETSKOG ISKUSTVA IZ TRIDESTIH GODINA PROŠLOG VEKA \\ Alessandro De Magistris}

Diskurs o realizmu u savremenoj arhitektonskoj raspravi izgleda da zaobilazi složenost istorijskih korena ove pojave u arhitekturi dvadesetog veka i, posebno, diskurs o socijalsitičkom realizmu: izvor mnogih perspektiva koje gravitiraju oko ideje realizma u posleratnom periodu i koje predstavljaju značajan momenat u teorijskoj raspravi i projektantskoj praksi između tridesetih i pedestih, sve do Staljinove smrti.

Cilj ovog članka je da predloži jedno artikulisano razmišljanje o iskustvu socrealizma, istraženog u njegovim "formativnim" godinama, u ključnoj fazi njegove razrade. Daleko od toga da je rezultat krutog, teoretskog određenja od vrha nadole, realizam je definisan na pragmatičan način, u većini radova projektanske prakse i teorije. Eklekticizam i pluralizam njegovih izražaja, koji gravitiraju oko ideje kritičke asimilacije istorije, objašnjava razvoj socrealizma između ratnog i posleratnog perioda u SSSR i istočno evropskim zemljama i nalazi svoj najjasniji iskaz u moskovskom metrou. 


\section{MANFREDO TAFURI I KRITIKA REALIZMA}

\section{Luka Skansi}

Jedna od glavnih tema istorijskog rada Manfreda Tafurija, bilo da je analizirao arhitekturu renesanse, iluminizma ili dvadesetog veka, ticala se odnosa između arhitektonskog stvaralaštva i stvarnosti. Ova tema takođe je premisa, odnosno uvodni teorijski okvir, za njegov istorijski i kritički diskurs "kritike realizma", koji je opisan u eseju Architettura e Realismo (Arhitektura i realizam), objavljenom 1985. godine. Ovaj esej predstavlja zaključne Tafurijeve opservacije italijanske posleratne arhitektonske kulture. Neorealizam postaje u njegovom eseju predmet prilično jedinstvene istorijske kontekstualizacije, predmet duboke kritike i, konačno, demistifikacije.

KLJUČNE REČI: ARHITEKTURA, REALIZAM, NEOREALIZAM, KRITIKA, POSLERATNA ITALIJA

\section{FRENK LOJD RAJT, EJN REND I HIPER-KAPITALISTIČKA UTOPIJA}

\section{Tijana Vujošević}

Ovaj rad predstavlja paralelno čitanje Frenk Lojd Rajtovog traktata Iščezavajući grad i Ejn Rendovog romana The Fountainhead. Autorka istražuje retoriku anti-urbanih utopija iz ere Depresije isnspirisanu mitom američkih pionira i osvajanjem granice. Ona identifikuje tri karakteristike Rajtovih i Rendovih anti-urbanih konstrukta: slavljenje muževnosti, poricanje političkog angažmana i anti-intelektualizam, sve to kombinovano u snu prvobitnog, idealnog kapitalizma. Koje su protivrečnosti i nedoslednosti svojstvene u građenju anti-urbane utopije? Ovo je pitanje na koje ovaj rad namerava da odgovori.

KLJUČNE REČI: MODERNIZAM, UTOPIJSKA FIKCIJA, ANTI-URBANIZAM, USONIA, THE FOUNTAINHEAD -

FAUNTEJNHED, IDEOLOGIJA, MUŠKOST, ANTI-INTELEKTUALIZAM

\section{MESTO [PROSTOR] NE-MESTO \\ Krunoslav Ivanišin}

Čak iako se nikada ne materijalizuju kao zgrade, arhitektonski projekti pripadaju stvarnom svetu. Odvojeno od stvarnog prisustva, ali bez lišavanja merljivih prostornih osobina, ovi skupovi tehničkih crteža u srazmeri, opisa i proračuna objašnjavaju buduću fizičku relanost u pogledu prostora, materijalnosti i forme, sa ciljem stvaranja sveta bar malo boljeg nego što je onaj iz koga potiču. Topografski izazovno, divno mesto pored mora; neko specifično gusto urbano okruženje; intrigantan način razmišljanja : neposredni kontekst prethodi i prati stvarnu izgradnju arhitektonskog dela. To je očigledna činjenica sama po sebi koju istoricističke konceptualizacije i klasifikacije ne mogu da poreknu. UTOPIJSKI ili REALISTIČNI, arhitektonski projekti su po svojoj prirodi vezani za mesta. Samo mera njihovog mešanja i uplitanja sa tim mestima može da varira. U našem post-globalizovanom svetu, i utopijski i realistični kvaliteti se mogu naći u projektima koji su hiperrealistični prema neposrednom kontekstu i koji se kontekstima bave minimalno, samo u pogledu raspoređivanja opterećenja, prilagođavanja stvarnoj topografiji, ili klimatskoj zaštiti.

KLJUČNE REČI: MESTO, ARHITEKTA, PROJEKAT, MATERIJAL, [PROSTOR], KONTEKTS, ARHITEKTURA, NE- MESTO 